Federal Reserve Bank of Minneapolis

Research Department

\title{
Bank Liability Insurance Schemes Before 1865*
}

\author{
Warren E. Weber \\ Working Paper 679
}

Revised December 2011

\begin{abstract}
Prior to 1861, several U.S. states established bank liability insurance schemes. One type was an insurance fund. Member banks paid into a state-run fund that paid bank creditors' losses. A second scheme was a mutual guarantee system. Member banks were legally responsible for the liabilities of any insolvent bank. This paper's hypothesis is that the moral hazard problem was controlled under a scheme to the degree that member banks had the power and incentive to control or modify others' risk-taking behavior. Schemes that gave member banks both strong incentives and power were able to control the moral hazard problem better than schemes in which one or both features were weak. Empirical evidence on bank failures and losses on banks' asset portfolios is consistent with this hypothesis.
\end{abstract}

Keywords: Deposit insurance; Moral hazard; Banknotes

JEL: E42, N21

*Federal Reserve Bank of Minneapolis, e-mail: weweber@gmail.com. I thank Todd Keister, Robert Lucas, Cyril Monnet, Arthur Rolnick, Eugene White, Ariel Zetlin-Jones, Ruilin Zhou, and participants at seminars at the Board of Governors and the Federal Reserve Bank of Chicago for helpful comments. The views expressed herein are those of the author and not necessarily those of the Federal Reserve Bank of Minneapolis or the Federal Reserve System. 


\section{Introduction}

Moral hazard is inherent in all insurance. Bank liability insurance is not an exception, as our recent financial experience attests.

Today, bank deposit liabilities are insured by the Federal Deposit Insurance Corporation (FDIC), established by the Banking Act of 1933. However, the FDIC was not the first bank liability insurance scheme in the United States. Six states enacted such schemes prior to the Civil War. Although the banking industry in the first half of the 19th century was quite different from what it is today, the moral hazard problems generated by these schemes were similar. ${ }^{1}$

Although there were differences in the exact details of these insurance schemes in the states that enacted them, they were of two basic types. One was an insurance fund sometimes called a Safety Fund. The other insurance scheme was a mutual guarantee system.

In the insurance fund schemes, member banks paid a percentage of capital into a fund controlled by a state banking authority. This authority would then use this fund to make payments to creditors of failed banks. Payments were capped initially by the amount in the fund. However, after such payments were made, there was mutualization of losses because the remaining solvent banks (survivors) potentially could be required to once again contribute to the fund to restore it to its requisite level. The responsibility for supervising member banks lay with a state banking authority, which had limited powers. Individual banks had little or no ability to control or modify the risk-taking behavior of other banks in the system.

The mutual guarantee systems did not have insurance funds. Instead, creditors of member banks that became insolvent were reimbursed directly and immediately out of the assets of surviving banks. The body overseeing these systems was a Board of Directors, and its powers were greater than those of the banking authorities in the insurance fund states. Further, individual banks had direct power to control or modify the risk-taking behavior of other banks in the system because each bank in the system had a representative on the Board.

Insurance funds schemes were enacted in three states: Michigan, New York, Vermont. Indiana, Iowa, and Ohio set up mutual guarantee systems. Here I focus on only four of these states, New York, Vermont, Indiana, and Ohio. I omit the schemes in Michigan and Iowa because they were in operation for only a short period of time. I find that the experience of the four states in terms of their ability to control moral hazard was quite different. My hypothesis is that the differences are consistent with the notion that how well a bank liability insurance scheme controlled moral hazard depended on how much power and incentive the banks involved in the scheme had to take actions to control or modify other member banks' risk-taking behavior. These differences also demonstrate that both power and incentives to directly affect other member banks' risk-taking behavior are important. Schemes with both features control moral hazard better than those with only one.

The paper proceeds as follows. In the next section, I describe how the two types of

\footnotetext{
${ }^{1}$ That moral hazard could be a problem with bank liability insurance schemes was recognized from the beginning. According to Chaddock (1910), 265, during the debate on the New York Safety Fund law, "another representative, Mr. Hubbell, pointed out that the very existence of such a fund would relax 'public scrutiny and watchfulness which now serve to restrain or detect malconduct.' "
} 
insurance schemes differed in terms of how much power banks had to affect the risk-taking behavior of each other. I also show that the banks in mutual guarantee systems had more power over other banks than did banks in the insurance funds. In the third section, I rank the insurance schemes in the four states in terms of how much incentive an individual bank had to control or modify the risk-taking behavior of other banks in the system. I show that the banks in the New York Safety Fund had the weakest incentives and that those in Indiana's mutual guarantee system had the greatest. In Section 4, I analyze how well these schemes controlled moral hazard by examining empirical evidence on bank suspensions of specie payments, bank failures and losses on banks' asset portfolios is consistent with this hypothesis. I find that the evidence bank failures and losses on banks' asset portfolios aligns well with my hypothesis. The evidence on suspensions of specie payments does not. The final section has a summary and concluding remarks.

\section{Power to change risk-taking behavior}

\section{A. Insurance funds}

The New York Safety Fund was established in 1829. Banks chartered after the Safety Fund law was passed were required to join the fund. ${ }^{2}$ Although the New York fund technically lasted until 1863, it effectively stopped providing insurance after 1842.

The Vermont insurance fund was established in 1831. Banks chartered after 1831 were required to join the fund. However, after 1841 newly chartered banks could choose whether or not to join, and rechartered banks could choose whether or not to continue in the fund. ${ }^{3}$ The result was that beginning in 1859 the Vermont fund had no participating banks.

Both insurance funds had virtually the same basic structure. Upon joining, member banks were required to pay a percentage of their capital into a fund managed by the state. These rates were $0.5 \%$ of capital per year up to a maximum of $3 \%$ in New York and $0.75 \%$ of capital per year up to a maximum of $4 \frac{1}{2} \%$ of capital in Vermont. Both funds guaranteed all of the liabilities of banks in the fund. ${ }^{4}$

The activities of the banks in the fund were supervised by bank commissioners employed by the state. ${ }^{5}$ The bank commissioners, of which there were only three in each state, were given full access to bank records. However, the power of these commissioners was limited. In New York, a bank could be closed only if it were "insolvent, or shall have violated any of the provisions of their act or acts of incorporation" (New York law, sec. 18). Similarly, the bank commissioners in Vermont could close banks only if they were insolvent or had violated the provisions of the act establishing the safety fund. Banks in the New York

\footnotetext{
${ }^{2}$ Banks chartered before the law was passed did not have to join. However, 16 of the 40 existing banks chose to be rechartered and be a part of the system, and 11 new banks were chartered when the law was passed.

${ }^{3}$ If a bank chose not to participate in the fund, the bank's directors had to post personal bonds equal to the bank's capital. If a rechartered bank chose not to rejoin the Vermont fund, its contribution was returned as was the case with New York Safety Fund banks.

${ }^{4}$ The exception was that beginning in 1837 New York provided that noteholders, but not depositors or other creditors, would be paid immediately. However, payments from the New York Safety Fund to noteholders could only continue as long as one-third of the capital of the fund (which amounted to $\$ 914,342.24$ on January 1, 1841) was held to meet debts other than notes of insolvent banks.

${ }^{5}$ The establishment of such supervisory agencies was an innovation at the time.
} 
and Vermont insurance funds could not be closed simply for bad management or taking on too risky a portfolio of loans.

More importantly, from the point of view of this paper, in neither state did the laws contain any provision for banks to directly affect the risk-taking behavior of the other banks in the system. In New York, for example, the most that a bank could do was get a bank examined "more frequently than once every four months, if required to do so by any three of the moneyed corporations subject to the provisions of this act" (sec. 16). Vermont's law contained no provisions concerning member banks' ability to monitor each other.

\section{B. Mutual Guarantee Systems}

The mutual guarantee systems went under the name of "State Bank of ...," or "Bank of the State of ..." Banks that were members of the systems were called branches. For example, the bank in Indianapolis that was a member of the Indiana system was called the Indianapolis Branch of the State Bank of Indiana. The State Bank of Indiana had 13 branches. The State Bank of Ohio had 41 branches, although throughout most of its existence fewer than 41 were in operation. The State Bank of Indiana was in existence from 1834 until 1857, when it ceased doing business before its charter expired in 1859. It was replaced by the Bank of the State of Indiana, which was another mutual guarantee system. The State Bank of Ohio began in 1845 and lasted until 1863, when its branches converted to national banks.

Despite being called branches, the member banks of these systems were independent banks, not branches of a parent bank. Each branch had its own stockholders and issued its own notes that were redeemable only at that branch. Further, "its own profits [were to] be divided among its own Stockholders" (sec. 14 of the Indiana law). The entity known as the "State Bank of ..." did no actual banking business whatsoever.

These systems were mutual guarantee schemes because each branch was responsible for at least some of the liabilities of the other branches. In Indiana, the branches mutually guaranteed "all debts, notes, and engagements of each other." 6 In Ohio, the law stated that "[e]ach solvent branch shall contribute ... to the sum necessary for redeeming the notes of the failing branch." 7

Each system was overseen by the Board of Directors of the State Bank. The powers of the Board of Directors in both Indiana and Ohio were greater than that of the bank commissioners of the insurance funds. For example, the Board of Directors of the State Bank of Indiana was required to suspend a branch's operations if a branch was "insolvent, or is mismanaging its affairs, whereby the interest of other Branches is endangered, ...or [has] refused to comply with any legal order or directions of the Board of Directors of the State Bank." (sec. 44, italics added). Further, it had the "power to limit and control the amounts of discounts and loans of the Branches after they amount to once and a quarter the amount of capital stock paid in" (sec. 40) and to "regulate and control the dividends of profits so that the capital stock shall never be diminished" (sec. 54). ${ }^{8}$

\footnotetext{
${ }^{6}$ State of Indiana (1849), sec. 9, p. 6.

${ }^{7}$ State of Ohio (1845), sec. 26, p. 35.

${ }^{8}$ As an example that the Board of Directors of the State Bank of Indiana utilized these powers, it wrote to the Lafayette Branch in 1838:
} 
More importantly, from this paper's viewpoint, the laws under which the mutual guarantee systems operated gave individual banks the direct ability to regulate the behavior of the other member banks. The Board of Directors of the State Bank in both systems was comprised of members appointed by the state legislature and one director from each branch.

\section{Incentives to change risk-taking behavior}

Under all of these systems, the other banks had a direct, one-sided financial stake in the outcome of the other banks. A bank could possibly share the losses (the downside) incurred by another bank. In the insurance fund scheme, this occurred because banks were potentially subject to additional assessments whenever the fund was reduced by payments to creditors of failed banks. Further, these assessments could continue until the funds returned to their requisite amounts, so that, in effect, banks could continue to be assessed without limit. In the mutual guarantee scheme, this occurred because any losses were paid immediately out of the assets of the surviving branches. If the losses were large enough, a branch's capital could be completely wiped out by the failure of another branch. However, a bank did not share in the profits (the upside) of another bank. Those profits went strictly to the shareholders of that bank.

As a result, it would seem that the banks in all four of these schemes had incentives to control and modify the risk-taking behavior of other banks. To determine the extent to which banks in these schemes were exposed to the risks taken by other banks, I computed the potential exposure to loss of an average bank that was a member of one of these insurance schemes if an average bank in the scheme failed.

\section{A. New York}

For banks in the New York Safety Fund, I computed the potential exposure to losses from a the failure of an average bank in the system as

$$
\text { exposure }=\frac{1}{N-1}\left\{\frac{(\text { insured liabilities minus } 0.5 \text { assets }) \text { of average failing bank }}{\text { capital of average surviving bank }}\right\} \text {, }
$$

where $N$ is the number of banks in the insurance scheme before the failure. That is, I computed the fraction of capital that the average surviving member bank would have to pay

The requirement of Mr. [the cashier of the branch]'s resignation was not considered by any one of the State Board as a matter personal towards him, but he had been guilty of several matters which the Branch board had refused to disapprove.... All that the State board expect is that your branch shall by its safe, prudent and honorable management recover and retain public confidence.... I suppose this might be done much more effectually even than by removing the Cashier if your Directors who are large borrowers would resign and the places could be supplied by prudent sensible men, not borrowers.... The State Board must have assurance that matters will be managed otherwise or your branch must and will be suspended. (from Golembe and Warburton (1958), IV-20)

The cashier resigned. Others examples are that the Lawrenceburg branch was suspended for a time for showing favoritism to certain stockholders and directors in making loans and the Bedford, Michigan City, and South Bend branches were also criticized for their lending practices. Golembe and Warburton (1958), IV-21 
creditors of an average failing bank.

In this computation, I assumed the assets of the failing bank were only enough to cover half of its outstanding liabilities. The reason for reducing the amount for which surviving banks would be responsible by some fraction of the assets of the failed banks is that under the New York Safety Fund system creditors would be paid first out of any receipts from the sales of assets of the failed bank. Only after the asset recovery process had been completed would creditors be paid out of the Safety Fund and only then would other insured banks be assessed to replenish the Fund. My assumption that the recovery rate of $50 \%$ is arbitrary, but as will be seen below it is in the ballpark of what was actually recovered in the case of New York Safety Fund bank failures.

Table 1 displays the number of banks in the Safety Fund for which I have data, their average capital, the average amount due from the Fund from the failure of an average bank, and the exposure such a failure would mean in terms of dollars and as a fraction of average capital. ${ }^{9}$ The table shows that for a New York Safety Fund bank, the exposures were quite small: less than $1 \%$ of capital for a bank with a capital stock equal to the average. This means that if one bank that was a member of the Safety Fund were to fail and its assets were only enough to cover half of its outstanding liabilities, then every other bank would be liable for an amount equal to approximately $1 \%$ of its capital stock to restore the Fund. These numbers remain small: $3 \%$ of capital (or less) for New York banks even under the extreme assumption that no assets of the failed bank were ever available to pay off creditors. ${ }^{10}$

\begin{tabular}{lccccc} 
Date & $\begin{array}{c}\text { Number of } \\
\text { banks } \\
\text { reporting }\end{array}$ & $\begin{array}{c}\text { Average } \\
\text { capital }\end{array}$ & $\begin{array}{c}\text { Average } \\
\text { due creditors } \\
\text { from Fund }\end{array}$ & \multicolumn{2}{c}{$\begin{array}{c}\text { Exposure } \\
\% \text { of } \\
\text { capital }\end{array}$} \\
\hline $1 / 1 / 1835$ & 76 & 345,151 & 165,435 & 2,206 & 0.6 \\
$1 / 1 / 1836$ & 77 & 344,564 & 241,979 & 3,184 & 0.9 \\
$1 / 1 / 1837$ & 89 & 358,443 & 249,637 & 2,837 & 0.8 \\
$1 / 1 / 1838$ & 87 & 361,380 & 110,438 & 1,285 & 0.4 \\
\hline
\end{tabular}

Table 1: Exposure of banks in the New York Safety Fund, 1835-1838

However, in actuality the exposures of New York Safety Fund banks were less than the computations in Table 1 indicate, because the link between the failure of a bank and losses to other banks was indirect for two reasons. The first is that there was a cap of $0.5 \%$ of capital per year on how much a bank could be required to contribute. The second is that the additional assessments that surviving would face due to a bank's failure would not begin until the failing bank had been liquidated, which could take a substantial period of time.

The evidence on how special assessments were handled illustrates the length of the delay between bank failures and assessments on the remaining solvent banks. New York

\footnotetext{
${ }^{9}$ The table is limited to the years 1835-1838 because these are the only years during which the Fund was operating and for which good data exist. The number of banks does not equal the number of banks in the Fund because not all banks reported at the times given in the table.

${ }^{10}$ This assumption is extreme because all failing banks had some specie on hand that could be used to pay creditors.
} 
experienced one bank failure in 1837 and six more in 1840 and 1841 . Yet, banks that were still members of the Safety Fund were not subject to special assessments until January 1842, and although the Fund had not been restored to its requisite level, (almost) no special assessments took place in 1844. Additional assessments began again only when special bonds were issued by the state in 1845 to pay off the creditors of the failed banks. They continued until 1866 when these bonds were fully paid off.

\section{B. Vermont}

I compute the potential exposures of banks in the Vermont Safety Fund using the same formula that I used for the New York Safety Funds banks. The exposures are displayed in Table 2. The exposures of a Vermont Safety Fund bank with a capital stock equal to the average were larger than those of New York banks, but they are still mostly below 5\% of capital. However, they rise to between $10 \%$ and $20 \%$ under the assumption that no assets of a failed bank were available to pay off creditors.

\begin{tabular}{|c|c|c|c|c|c|c|}
\hline \multicolumn{2}{|l|}{ Date } & $\begin{array}{l}\text { Number of } \\
\text { banks } \\
\text { reporting }\end{array}$ & $\begin{array}{c}\text { Average } \\
\text { capital }\end{array}$ & $\begin{array}{c}\text { Average } \\
\text { due creditors } \\
\text { from Fund }\end{array}$ & \multicolumn{2}{|c|}{$\begin{array}{l}\text { Exposure } \\
\% \text { of }\end{array}$} \\
\hline July-October & 1833 & 7 & 42,857 & 23,660 & 3,943 & 9.2 \\
\hline August-October & 1835 & 9 & 48,333 & 28.490 & 3,561 & 7.4 \\
\hline July-October & 1837 & 11 & 56,364 & 19,493 & 1,949 & 3.5 \\
\hline September-October & 1839 & 11 & 56,436 & 29,510 & 2,951 & 5.2 \\
\hline August & 1840 & 10 & 59,629 & 12,534 & 1,393 & 2.3 \\
\hline June-October & 1843 & 15 & 64,667 & 16,533 & 1,181 & 1.8 \\
\hline August & 1845 & 13 & 64,489 & 17,692 & 1,474 & 2.3 \\
\hline August-September & 1848 & 14 & 78,693 & 13,699 & 1,054 & 1.3 \\
\hline August & 1850 & 10 & 90,311 & 31,435 & 3,493 & 3.9 \\
\hline July-August & 1852 & 10 & 97,500 & 42,158 & 4,684 & 4.8 \\
\hline July-August & 1855 & 7 & 89,286 & 34,839 & 5,806 & 6.5 \\
\hline
\end{tabular}

Table 2: Exposure of banks in the Vermont Safety Fund, selected years, 1833-1855

However, for the same two reasons that the exposures of New York Safety Fund banks were actually smaller than indicated by the computations in Table 1, the exposures of Vermont Safety Fund banks also were actually smaller than those shown in Table 2. Like New York, Vermont banks had a cap ( $0.75 \%$ of capital per year) on how much a bank could be required to contribute to restore the fund after a bank failure.

Once again, the evidence on how special assessments were handled illustrates the length of the delay between bank failures and assessments on the remaining solvent banks. The first failure of a Vermont Safety Fund bank was the Essex County Bank. It failed in 1839. The remaining banks that were members of the Vermont insurance fund did not face special assessments until 1852. Further, these assessments ended in 1855. No assessments were made after the only other failure, that of the Danby Bank in 1857, because there were no banks remaining in the fund at this point. 


\section{State Bank of Indiana}

Because the payments to creditors of failed banks were to be made immediately from the assets of the surviving banks, I calculated the exposure of the branches of the State Bank of Indiana differently than I did for the banks in the New York and Vermont insurance fund schemes. Specifically, I calculated the exposure as

exposure $=\frac{1}{N-1}\left\{\frac{(\text { insured liabilities minus "cash and cash items") of average failing branch }}{\text { capital of average surviving branch }}\right\}$,

In other words, I assumed that only the cash on hand in the failing branch could be used to immediately pay creditors. The remainder had to be paid immediately from the assets of the surviving branches.

Table 3 displays the exposures of the branches of the State Bank of Indiana. Although these numbers vary between $5 \%$ and $29 \%$, for the most part they are around $16 \%$. The major reason why the exposure was so high is that there were only a few branches (the maximum was 13) over which to spread the losses.

\begin{tabular}{lccccc} 
& $\begin{array}{c}\text { Number of } \\
\text { bbranches } \\
\text { reporting }\end{array}$ & $\begin{array}{c}\text { Average } \\
\text { capital }\end{array}$ & $\begin{array}{c}\text { Average } \\
\text { due creditors } \\
\text { from Fund }\end{array}$ & $\begin{array}{c}\text { Exposure } \\
\% \text { of } \\
\text { capital }\end{array}$ \\
\hline $11 / 21 / 1835$ & 10 & 119,978 & 258,454 & 27,828 & 27.8 \\
$11 / 26 / 1836$ & 11 & 144,134 & 423,440 & 42,344 & 29.4 \\
$9 / 2 / 1837$ & 11 & 167,727 & 317,544 & 31,754 & 18.9 \\
$11 / 17 / 1838$ & 13 & 170,515 & 210,692 & 17,558 & 10.3 \\
$11 / 21 / 1840$ & 13 & 205,509 & 218,920 & 18,243 & 8.9 \\
$11 / 21 / 1841$ & 13 & 211,015 & 220,989 & 18,416 & 8.7 \\
$11 / 21 / 1842$ & 13 & 209,810 & 134,620 & 11,218 & 5.4 \\
$11 / 21 / 1843$ & 13 & 163,889 & 152,968 & 12,747 & 7.8 \\
$11 / 21 / 1844$ & 13 & 161,478 & 212,390 & 17,699 & 11.0 \\
$11 / 21 / 1845$ & 13 & 154,453 & 254,438 & 21,203 & 13.7 \\
$11 / 21 / 1846$ & 13 & 160,294 & 269,842 & 22,487 & 14.0 \\
$11 / 20 / 1847$ & 13 & 160,221 & 301,638 & 25,136 & 15.7 \\
$11 / 17 / 1849$ & 13 & 160,224 & 287,097 & 23,925 & 14.9 \\
$11 / 16 / 1850$ & 13 & 160,227 & 290,272 & 24,185 & 15.1 \\
$10 / 31 / 1851$ & 13 & 160,231 & 313,202 & 26,100 & 16.3 \\
$11 / 2 / 1852$ & 13 & 160,231 & 360,099 & 31,008 & 18.7 \\
$10 / 31 / 1853$ & 13 & 165,393 & 366,230 & 30,519 & 18.4 \\
$10 / 31 / 1854$ & 13 & 165,393 & 300,641 & 25,053 & 15.2 \\
$10 / 31 / 1855$ & 13 & 164,953 & 346,788 & 28,899 & 17.5 \\
$10 / 31 / 1856$ & 13 & 165,393 & 368,905 & 30,742 & 18.6 \\
\hline
\end{tabular}

Table 3: Exposure of branches of the State Bank of Indiana, 1835-1856 


\section{State Bank of Ohio}

The State Bank of Ohio mutual guarantee scheme only covered noteholders. For this reason, computed the exposures of the Branches as

$$
\text { exposure }=\frac{1}{N-1}\left\{\frac{(\text { circulation minus "cash and cash items") of failing branch }}{\text { capital of average surviving branch }}\right\},
$$

In other words, I assumed that the notes were the only liabilities that had to be paid off and that the cash on hand in the failing branch could be used to immediately pay noteholders. The remainder had to be paid immediately from the assets of the surviving branches.

Table 4 displays the exposures of the branches of the State Bank of Ohio. They are on the order of $3.5 \%$. They are substantially lower that the exposures of the branches of the State Bank of Indiana, however. There are two reasons for this. First, only notes were covered; second, there were more branches over which to spread potential losses.

\begin{tabular}{lccccc} 
Date & $\begin{array}{c}\text { Number of } \\
\text { branches } \\
\text { reporting }\end{array}$ & $\begin{array}{c}\text { Average } \\
\text { capital }\end{array}$ & $\begin{array}{c}\text { Average } \\
\text { due creditors } \\
\text { from Fund }\end{array}$ & $\begin{array}{c}\text { Exposure } \\
\text { \% of } \\
\text { capital }\end{array}$ \\
\hline $2 / 1 / 1846$ & 16 & 64,420 & 56,794 & 3,786 & 5.9 \\
$11 / 1 / 1846$ & 16 & 87,297 & 105,448 & 6,590 & 7.6 \\
$5 / 1 / 1848$ & 37 & 89,240 & 96,507 & 2,608 & 2.9 \\
$11 / 1 / 1849$ & 40 & 110,690 & 136,814 & 3,420 & 3.1 \\
$2 / 1 / 1851$ & 41 & 115,793 & 161,646 & 3,942 & 3.4 \\
$2 / 1 / 1854$ & 38 & 113,005 & 156,595 & 4,121 & 3.6 \\
$11 / 1 / 1854$ & 37 & 110,932 & 141,189 & 3,816 & 3.4 \\
$2 / 1 / 1856$ & 36 & 113,736 & 159,429 & 4,428 & 3.9 \\
$11 / 1 / 1856$ & 36 & 114,292 & 159,969 & 4,444 & 3.9 \\
$2 / 1 / 1858$ & 32 & 116,391 & 120,874 & 3,777 & 3.2 \\
$11 / 1 / 1858$ & 36 & 114,569 & 148,049 & 4,112 & 3.6 \\
$2 / 1 / 1860$ & 35 & 115,307 & 149,027 & 4,259 & 3.7 \\
\hline
\end{tabular}

Table 4: Exposure of branches of the State Bank of Ohio, 1846-1860

These exposures are also greater than those of the banks in the New York Safety Fund, but are on the order of those in the Vermont Safety Fund. Nonetheless, I would argue that the exposure of the branches of the State Bank of Ohio was greater than that of the Vermont Safety Fund banks because the branches could be called on immediately to pay the insured creditors of the failed branch. No delay would occur, as was the case with the Vermont insurance fund. If a receiver were to subsequently get something for the assets of the failed branch, these receipts would be rebated to the other branches. However, that process could take a long time, but the payments to the creditors of the failed bank immediately went out the doors of the other branches. 


\section{Degree of control of moral hazard}

Table 5 displays a summary of the above discussion of the power and incentives that banks in these bank liability insurance schemes had to control or modify the risk-taking behavior of other banks in the scheme. Banks in the New York and Vermont Safety Fund schemes had no power and weak incentives to control or modify the behavior of other banks. Under our hypothesis, moral hazard should have been poorly controlled in these systems. At the other extreme, Branches of the State Bank of Indiana had both strong power and incentives to control other branches, and according to our hypothesis, moral hazard should have been well controlled in this scheme. The Branches of the State Bank of Ohio had the same power as the branches of the State Bank of Indiana but their incentive to control the behavior or other branches was weaker because only notes were insured. Therefore, the control of moral hazard should have been better than under the two safety fund schemes, but not as good as for the State Bank of Indiana.

\begin{tabular}{cc|c|c|}
\multicolumn{1}{c}{} & \multicolumn{2}{c}{ power } \\
\cline { 3 - 4 } none & \multicolumn{2}{c|}{ strong } \\
\cline { 3 - 4 } incentives & weak & $\begin{array}{c}\text { New York Safety Fund } \\
\text { Vermont Safety Fund }\end{array}$ & \\
\cline { 3 - 4 } & strong & & State Bank of Ohio \\
\cline { 3 - 4 } & & State Bank of Indiana \\
\cline { 3 - 4 } & &
\end{tabular}

Table 5:

In this section I examine the extent to which the experience of these insurance schemes in controlling moral hazard aligns with my hypothesis. To do this, I measure the degree of control of moral hazard in three ways: by the frequency and duration of suspensions of bank note redemption, by the number of bank failures, and by the sizes of losses on the asset portfolio of failed banks.

\section{A. Bank suspensions}

Bank liability insurance removes the incentive for creditors to monitor banks. As a result, the moral hazard problem could show up as banks holding smaller amounts of specie and hence being more susceptible to runs. Other banks in the insurance scheme, however, would have the incentive to regulate the specie-holding behavior of other banks, because a run on one bank could spread to other, sound banks. Less frequent suspensions or suspensions of shorter duration would provide evidence that moral hazard was better controlled to the degree that banks had to regulate this behavior.

I find that the evidence from bank suspensions does not align well with the ranking suggested above. Bank suspensions were less frequent and of shorter duration for New York and Vermont Safety Fund banks, which had little power to regulate other banks, than for branches of the State Bank of Indiana, which had a lot of power to regulate other branches. Further, branches of the State Bank of Ohio, which had the same power but less incentive 
to regulate other branches as did branches of the State Bank of Indiana, never suspended.

The first major bank suspension episode that occurred after some of these insurance schemes were in place began in May 1837. All banks in the three insurance schemes in existence at the time suspended specie payments on their notes. New York Safety Fund banks suspended on May 9, 1837; Vermont Safety Fund banks, on May 10; branches of the State Bank of Indiana, prior to May 19.

However, the suspensions of the New York and Vermont Safety Fund banks were of shorter duration than the suspension by the State Bank of Indiana. The New York and Vermont Safety Fund banks resumed in May 1838. The State Bank of Indiana did not resume until August 13, 1838. Further, the State Bank of Indiana suspended again in November 1839 and did not resume payments until June 15, 1842. The Safety Fund banks in New York and Vermont did not suspend for a second time in the fall of 1839.

The second major bank suspension that occurred after some of these insurance schemes were in place occurred in late 1857. The only insurance scheme that was effectively in existence was the State Bank of Ohio. The New York Safety Fund had essentially ceased being able to provide insurance, Vermont's insurance fund had almost no banks as members, and the State Bank of Indiana ceased doing business on January 1, 1857.

The branches of the State Bank of Ohio did not suspend during this panic. ${ }^{11}$ However, the argument can be made that the State Bank of Ohio put in place a partial suspension, because it took extraordinary actions to make it more difficult for noteholders to present notes for redemption. In particular, it permitted branches to pay out notes of other Branches (such a practice was usually prohibited), making it more difficult for notes to be presented for redemption. To help facilitate this, "the clerk of the Board of Control, upon receiving notes from one Branch Bank, would return a mixed package of notes of other, distant, Branch Banks." (Golembe and Warburton (1958), VI-30)

The differences in the suspension experiences may have had nothing to do with differences in the power and incentives that banks had to control the specie reserve behavior of other banks in an insurance scheme, however. The reason is that all banks, insured and uninsured, had a strong incentive not to suspend. All banks were legally prohibited from suspending specie payments on their notes. If a bank did suspend, banking authorities had the power to close the bank.

Nonetheless, there were times when specie payments were suspended. These suspensions occurred when for some reason a large number of banks in a city or state faced the possibility of running out of specie and therefore being unable to redeem their notes on demand. In such cases, banking authorities would usually permit widespread (citywide or statewide) suspensions of payments to occur with no threat of closing the banks. Since the conditions that would have led to suspensions were likely to have been general across regions and probably would have affected all banks whether insured or not, state banking authorities would have had difficulty permitting a certain class of banks to save specie and suspend while not allowing other banks facing the same specie demands to do the same.

As a result, the suspension and resumption behavior of insured and uninsured banks was similar within and across states in the same region. For example, in the Panic of 1837,

${ }^{11}$ The branches of the Bank of the State of Indiana, the mutual guarantee insurance system that replaced the State Bank of Indiana, also did not suspend during this panic(Van Vleck (1967), 73, n. 17). 
all banks in New York suspended and resumed at exactly the same time. The same was true for all banks in New England. The timing of the suspensions and resumptions of the State Bank of Indiana was similar to that of banks in Pennsylvania. And in the Panic of 1857, banks in Ohio that were not branches of the State Bank also did not suspend at this time. ${ }^{12}$

\section{B. Bank failures}

The moral hazard problem with bank liability insurance could also show up as insured banks holding riskier asset portfolios than noninsured banks. Therefore, insured banks should be more likely to fail than noninsured banks. Other banks in the insurance scheme, however, would have the incentive to regulate the riskiness of other banks' portfolios, because they could potentially share the losses due to a bank's failure but not share any gains if a bank were to continue in business. If control of moral hazard is greater to the degree that banks have the power and incentives to regulate the behavior of others (my hypothesis), then the State Bank of Indiana should have had the fewest failures, followed by Ohio. New York and Vermont should have had the highest failure rates.

\begin{tabular}{lcccc} 
& Number & Failed & Failure Rate & Received Aid \\
\hline State Bank of Indiana & 13 & 0 & 0 & 0 \\
State Bank of Ohio & 36 & 4 & 11.1 & 6 \\
New York Safety Fund & 90 & 10 & 11.1 & 0 \\
Vermont Safety Fund & 22 & 2 & 9.1 & 0 \\
\hline
\end{tabular}

Table 6: Failure rates for safety fund and mutual guarantee banks

The bank failure experience for the four insurance schemes is displayed in Table 6 . The experience of the State Bank of Indiana is consistent with my hypothesis, because the State Bank of Indiana experienced no bank failures. However, the bank failure evidence from the other three schemes aligns only moderately well with this ranking. The State Bank of Ohio, which should have had a higher failure rate than the State Bank of Indiana, in fact did. However, its failure rate should have been lower than that for banks in the New York and Vermont safety funds. In actuality, its failure rate was about the same or even higher if the number of banks that required additional assistance were included.

The reason the failure rates do not align more closely with the power and incentives of banks to regulate the behavior of other banks may be that for for New York, Vermont, and Ohio the incentive effect was small. As shown above, the expected loss to a bank from the failure of another bank in these schemes was a relatively small fraction of capital.

The bank failure data also allow another comparison. The control of bank risk-taking behavior by creditors of noninsured banks can be compared with the control that supervisors or other banks exerted over banks that are part of insurance schemes. I do this by doing a state-by-state comparison of the failure experience of insured banks with similar noninsured banks both within the state and in similar states.

\footnotetext{
${ }^{12}$ The exception was the Ohio Life and Trust Company. The Panic of 1857 is sometimes attributed to the failure of this bank.
} 


\section{New York}

During the period 1830-1843, which is roughly when the New York Safety Fund was actually insuring banks, two other types of banks were in existence in New York: chartered banks, banks that were in existence before the Fund was put in place and had been exempted from participating in it, and free banks. The number of each of these types of banks that were in existence, the number that failed, and the failure rates during this period are shown in Table 7. Also shown is the same information for banks in Massachusetts, New Jersey and Pennsylvania over the same period. These states were similar to New York in that they had large populations and well-developed banking systems since at least the early 1800s. Further, Massachusetts and Pennsylvania each had a major financial center. However, none of these states had a bank liability insurance scheme.

\begin{tabular}{lccc} 
& Number & Failed & Failure Rate \\
\hline New York Safety Fund, chartered & 90 & 10 & 11.1 \\
New York Non-Safety Fund, chartered & 10 & 0 & 0 \\
Massachusetts & 134 & 9 & 6.7 \\
Pennsylvania & 52 & 5 & 9.6 \\
New Jersey & 32 & 4 & 12.5 \\
New York free & 91 & 24 & 26.4 \\
\hline
\end{tabular}

Table 7: Failure rates for New York Safety Fund and non-Safety Fund banks, and for Massachusetts, New Jersey, and Pennsylvania banks, 1830-1843

The evidence in Table 7 is mixed as to how well risk-taking behavior was controlled for the Safety Fund banks as compared with the control exercised by creditors of noninsured banks. In support of the argument that risk-taking behavior was comparably not well controlled, the failure rate for Safety Fund banks was higher than that for chartered banks that were not in the Safety Fund and almost twice the failure rate for banks in Massachusetts. In support of the other position, the failure rate for New York Safety Fund banks was approximately the same as that for banks in New Jersey and Pennsylvania and was much lower than that for free banks, more than a quarter of which failed.

\section{Vermont}

Next, for the time period 1832-1858, I compare the failure rates of insured Vermont banks with those of noninsured Vermont banks and banks in Maine and New Hampshire. I choose these two states for comparison because they are in the upper part of New England and were similar to Vermont in terms of demographics. Neither state had an insurance fund.

The evidence in Table 8 is also mixed as to how well risk-taking behavior was controlled for the Safety Fund banks as compared witn the control exercised by creditors of noninsured banks. In support of the argument that risk-taking behavior was comparably not well controlled, the failure rate for Safety Fund banks was higher than that banks that were not in the Vermont Safety Fund and for banks in New Hampshire. In support of the argument that it was comparably well controlled, the failure rate for Vermont Safety Fund 


\begin{tabular}{lccc} 
& Number & Failed & Failure Rate \\
\hline Vermont in bank fund & 22 & 2 & 9.1 \\
Vermont not in fund & 41 & 2 & 4.9 \\
New Hampshire & 28 & 2 & 7.1 \\
Maine & 60 & 7 & 11.7 \\
\hline
\end{tabular}

Table 8: Failure rates for Vermont banks both in and not in the insurance fund and for Maine and New Hampshire banks, 1832-1858

banks was lower than that for banks in Maine.

\section{Ohio}

Lastly, I compare the failure rates for branches of the State Bank of Ohio with those of similar banks in the state at the time. During the period 1845-1860 when the State Bank of Ohio was in existence, there were effectively two other types of banks in the state: ${ }^{13}$

1. Independent banks - The law establishing the State Bank of Ohio also permitted banks to be organized under the same general restrictions as branches of the State Bank of Ohio except that instead of being part of the mutual guarantee system they had to "deposit with and transfer to the treasurer of state certificates of the funded debt of this state, or of the United States, at least equal in amount to the amount of its capital stock. ..."(State of Ohio (1845), sec. 30, p. 36)

2. Free banks - These were banks established after 1851 that operated under free banking laws.

The evidence in Table 9 is also mixed as to how well risk-taking behavior was controlled for the Safety Fund banks as compared to the control exercised by creditors of noninsured banks. In support of the argument that risk-taking behavior was comparably well controlled, the branches of the State Bank of Ohio had lower failure rates than the Independent banks. In support of the argument that it was not well controlled: If the number of number of branches that received aid is combined with the number failing, the failure rate of branches of the State Bank of Ohio becomes almost 28\%. Further, free Banks had a low rate of failures, 6.7 percent.

\section{Losses on assets of failed banks}

The moral hazard problem with bank liability insurance could also show up as losses on the asset portfolios of failed banks because insured banks have more incentive to hold riskier asset portfolios than do noninsured banks. Here, I present data on the size of losses on asset portfolios of failed banks that led to losses for creditors or to payments to creditors by the insurance fund or by other banks in the insurance scheme. If control of moral hazard

\footnotetext{
${ }^{13}$ I ignore the "Old banks," - banks chartered before 1845 that operated under their old charters - because most of them were in shaky financial condition when the State Bank of Ohio went into operation.
} 


\begin{tabular}{lcccc} 
& Number & Failed & Failure Rate & Received Aid \\
\hline State Bank Branches & 36 & 4 & 11.1 & 6 \\
& & & & 0 \\
Free banks & 15 & 1 & 6.7 & 0 \\
Independent banks & 13 & 2 & 15.4 & \\
\hline
\end{tabular}

Table 9: Failure rates for Ohio banks by type, 1845-1860

is greater the greater the power and incentives of banks to regulate the behavior of others, then, following the arguments made above, New York and Vermont should have had the largest losses on assets, and branches of the State Bank of Indiana should have had the smallest losses. The losses of failed branches of the State Bank of Ohio should have fallen somewhere in between.

The experience of the State Bank of Indiana is consistent with my hypothesis. There were no losses on the asset portfolios of failed branches because the State Bank of Indiana experienced no branch failures. However, as was the case with the bank failure evidence, the evidence on losses on the asset portfolios of failed banks under the other three schemes aligns only moderately well with the ranking suggested by my hypothesis.

\section{New York}

To estimate the amount of losses on the asset portfolios of the New York Safety Fund banks, I first estimated the amount of good assets that a bank had by subtracting the "Claims against the insurance system" as estimated by Golembe and Warburton (1958), Table 12 from the bank's total liabilities. My reasoning is that liabilities that were not paid by the Fund had to have been paid out of the assets of the bank, which meant that this assets would have been good. I then estimated the losses on the asset portfolio at time of failure as the difference between total assets and good assets. I use two measures of total assets at time of failure. The first, shown in column 3 of Table 10, is "Obligations at the last report prior to suspension or difficulty, Total" (Golembe and Warburton (1958), Table 11) plus total capital taken from the bank balance sheets in Weber (2012). The second, shown in column 4 , is total assets from the last available balance sheet in Weber (2012). ${ }^{14}$

My estimated losses in dollar terms are shown in column 5 of the table and in percentage terms in columns 6 and 7 . The losses were large, averaging about $80 \%$ to $85 \%$ of a failed bank's assets. ${ }^{15}$

\footnotetext{
${ }^{14}$ The dates of the last balance sheets are 1/1/1837 for the Lockport Bank, 1/1/1840 for the City Bank of Buffalo, 1/23/1841 for the Wayne County Bank and all the banks listed under 1841, and 1/1/1842 for all the banks listed under 1842 . For the $1 / 23 / 1841$ banks, the item used is total liabilities (which includes capital) rather than total assets because it appears that several asset items are omitted from the available balance sheets.

${ }^{15}$ I exclude the Lafayette Bank and Oswego Bank from these calculations. Given that the failure of these banks did not require pay outs by the Safety Fund, it is not possible to estimate their losses by my method except to say that the must have been less than the capital stocks of these banks which are the entries given in column 5 of the table.
} 


\begin{tabular}{llrrrrr} 
& & \multicolumn{2}{c}{ Assets } & \multicolumn{2}{c}{ Estimated losses } \\
Year & Bank & $\begin{array}{r}\text { Estimated } \\
\text { (see text) }\end{array}$ & $\begin{array}{c}\text { Balance } \\
\text { sheets }\end{array}$ & $(\$)$ & $\%(1)$ & $\%(2)$ \\
\hline 1837 & Lockport Bank & 237,000 & 348,608 & 136,000 & 57.4 & 39.0 \\
& & & & & \\
1840 & City Bank, Buffalo & 884,000 & 864,987 & 717,000 & 81.1 & 82.9 \\
& Wayne County Bank & 312,000 & 312,221 & 229,000 & 73.4 & 73.4 \\
& & & & & \\
1841 & Commercial, NY & $1,089,000$ & 936,674 & 786,000 & 72.2 & 83.9 \\
& Bank of Buffalo & 868,000 & 653,920 & 785,000 & 90.4 & 100 \\
& Commercial Bank, Buffalo & $1,213,000$ & $1,072,182$ & $1,012,000$ & 83.4 & 94.4 \\
& Commercial Bank, Oswego & 572,000 & 595,316 & 491,000 & 85.8 & 82.5 \\
& & & & & \\
& & 480,000 & 509,981 & 461,000 & 96.0 & 90.4 \\
& Watervliet Bank & 665,000 & 665,797 & $<500,000$ & $<75$ \\
& Lafayette Bank & 506,000 & 540,398 & 428,000 & 84.6 & 79.2 \\
Clinton County Bank & 349,000 & 445,012 & 296,000 & 84.8 & 66.5 \\
& Bank of Lyons & 327,000 & 337,086 & $<150,000$ & $<45$ \\
Oswego Bank & & & & & \\
Total 10 banks & $6,510,000$ & $6,279,299$ & $5,341,000$ & 82.0 & 85.1 \\
\hline
\end{tabular}

Table 10: Loss rates for New York Safety Fund banks, 1830-1843

\section{Vermont}

I estimated losses on the asset portfolios of the two Vermont insurance fund banks in the same way as I estimated the losses for the New York Safety Fund banks. The data come from Golembe and Warburton (1958) Table 19 and Weber (2012). In the calculation of good assets I use "Payments from insurance fund: Claimed" from Table 19. The estimated losses are displayed in Table 11. The estimated losses are between $50 \%$ and $60 \%$ of the failing bank. Even though these losses are lower than the average losses on the portfolios of New York Safety Fund Banks, they are still quite large.

\begin{tabular}{rlrrrrr} 
& & \multicolumn{2}{c}{ Assets } & \multicolumn{2}{c}{ Estimated losses } \\
Year & Bank & Estimated & Balance & & & \\
\hline 1839 & Essex Bank & 99,000 & 98,838 & 59,000 & 59.6 & 59.7 \\
1857 & Danby Bank & 133,000 & 156,729 & 81,000 & 60.9 & 51.7 \\
\hline
\end{tabular}

Table 11: Loss rates for Vermont insurance fund banks, 1839-1857 


\section{The State Bank of Ohio}

Estimating the losses on the asset portfolios for the four branches of the State Bank of Ohio that failed is not as straightforward as it was for the case of failed banks in New York and Vermont. The difficulty is that only note holders were covered under the State Bank of Ohio mutual guarantee system, and the information in Golembe and Warburton (1958) is the "Assessment for redemption of notes of failed Branch Banks, Amount collected." There is no information on the losses experienced by shareholders, depositors, or other creditors which would be required to estimate the losses on the asset portfolio.

\begin{tabular}{rrrrrr} 
& Bank & Assets & $\begin{array}{r}\text { "Safe" } \\
\text { assets }\end{array}$ & $\begin{array}{r}\text { "Risky" } \\
\text { assets }\end{array}$ & \% "Risky" \\
\hline 1852 & Licking County & 320,941 & 85,527 & 235,414 & 73.4 \\
1854 & & & & \\
& Akron & 419,676 & 104,004 & 315,672 & 75.2 \\
& Mechanics \& Traders & 318,881 & 93,048 & 225,833 & 70.8 \\
Commercial, Toledo & 637,176 & 199,991 & 437185 & 68.6 \\
& & & & 72.0 \\
Average all four & & & & 88.4 \\
Average NY Safety Fund & & & 89.1 \\
\hline
\end{tabular}

Table 12: Riskiness of assets portfolios of branches of the State Bank of Ohio, 1851-1854

Because of this difficulty I looked instead at the "potential riskiness" of the asset portfolios of the failed branches of the State Bank of Ohio in the last balance sheet in Weber (2012) before they failed and compared it with the average "potential riskiness" of the asset portfolios of the New York and Vermont Safety Fund banks before they failed. My measure of potential riskiness is the total assets of a bank less "Due from other banks," "Notes of other banks," and "Cash and cash items," which I deemed to be safe assets, in the sense that they would be subject to a low probability of loss. The results are given in Table 12. The table shows that on average branches of the State Bank of Ohio that failed held less risky portfolios than did banks that failed in New York and Vermont. Of course, this is not direct evidence that losses on the portfolios of the failed branches of the State Bank of Ohio were smaller, but it is suggestive that this could have been the case, consistent with my hypothesis.

\section{Summary and conclusion}

This paper examines the experience of New York, Vermont, Ohio, and Indiana under the different schemes for insurance bank liabilities that were in place in each state. It finds that the experience of these states in terms of the control of the moral hazard problem associated with any kind of insurance scheme was quite different. The paper's hypothesis is that these differences are consistent with the notion that a bank liability insurance scheme control moral hazard to the degree that the banks involved in the scheme have the power and incentive to take actions to control or modify other member banks' risk-taking behavior. 
Under this hypothesis, the control of moral hazard should have been the least in New York and Vermont, because banks had little incentive and little power to control the risk-taking behavior of other banks in the system. The control over moral hazard should have been the greatest in the State Bank of Indiana system, because both incentives and power were quite strong. The control of moral hazard in the State Bank of Ohio system should have been somewhere in between, because even though the incentives were about the same as those in New York and Vermont, an individual branch had the same power over the behavior of other branches and did the branches of the State Bank of Indiana.

This paper measures the control of moral hazard by how well bank suspensions were prevented, how low was the rate of bank failures, and how small were the losses on bank asset portfolios. The empirical evidence on bank failures and losses on bank asset portfolios is largely consistent with the hypothesis. The control of moral hazard was the weakest in New York and Vermont and the strongest in Indiana. The evidence on failures and losses for the State Bank of Ohio is only roughly consistent with the hypothesis, however, because its branches had roughly the same failure rates as banks in the New York and Vermont safety funds. It is also the case that the evidence on bank suspensions is not consistent with the hypothesis. However, there are good reasons to discount this evidence because of the laws governing suspension of specie payments gave all banks the same incentives to avoid suspensions,regardless of how they were insured or even if they were uninsured.

The lesson to be drawn from this exercise is that moral hazard in bank liability insurance schemes can be well controlled if the individual participants have both significant "skin in the game" and the power to change the behavior of other participants. However, as the contrast between experience of the branches of the State Bank of Ohio and the branches of the State Bank of Indiana shows, the power to change the behavior of other participants alone is not enough. Banks also have to have the incentive to modify the behavior of other banks. Unfortunately, there was no insurance scheme in existence in this period that would provide evidence about how well moral hazard would be controlled in a scheme in which member banks had strong incentives to modify the behavior of other member banks, but had little power to do so. Perhaps such such systems did not arise because they were not feasible. 


\section{References}

Chaddock, R. E. (1910): The Safety Fund Banking System in New York State, 1829-1866. S. Doc. No. 581, 61st Cong., 2nd sess., Government Printing Office, Washington, DC.

Golembe, C. H., and C. Warburton (1958): "Insurance of Bank Obligations in Six States During the Period 1829-1866," Federal Deposit Insurance Corporation.

State of Indiana (1849): "An Act Establishing a State Bank," in Charter of the State Bank of Indiana. Chapmans \& Spann, Indianapolis.

State of Ohio (1845): "An Act to Incorporate the State Bank of Ohio and Other Banking Companies," in Acts of a General Nature Passed by the Forty Third General Assembly of the State of Ohio, vol. 43. Samuel Medary, Columbus.

Van Vleck, G. W. (1967): The Panic of 1857, An Analytical Study. AMS Press, Inc., New York.

Weber, W. E. (2012): "Balance sheets for U.S. Antebellum State Banks," Research Department, Federal Reserve Bank of Minneapolis, http://www.minneapolisfed.org/research/ economists/wewproj.cfm. 